\title{
Quality Characteristics of Jam and Whole Destoned Cherries Processed Using Sour and Sweet Cherries
}

\author{
Karl Kaack \\ Aarhus University, Kirstinebjergvej 10 Aarslev, Denmark.
}

\begin{abstract}
This research includes the steps from selection of raw to industrial processing of jam, and whole destoned cherries using high quality raw materials from seven cultivars including 'Stevnsbcer clone 23' and 'Kelleris 16' as representatives for sour and sweet cherries, respectively. The six cultivars applied for processing of cherry fruit jam varies significantly in fruit weight, stone, acidity, soluble solids and especially the contents of colorants. Equilibrium in weight, brine and fruit were obtained after storage at $20^{\circ} \mathrm{C}$ for six days. Acidity in brine and fruit increased and decreased significantly in 73 days, respectively. Increasing content of sugar resulted in significantly increases in net weight, brine and cherries, whereas weight of cherries and acidity were constant and cherry volume decreased significantly. During pasteurization for up to 73 days were the weight was stable, while brine increased, cherries, volume and anthocyanin decreased significantly and benzaldehyde was unaffected by pasteurization. Lightness decreased, redness increased, yellowness decreased and anthocyanin increased with storage time. Increasing brix resulted in increasing cherry brix, density, fruit weight, brine weight, while fruit cherry weight and berries weight were unaffected by the brix level. Acidity and cherry increased and cherry fruit volume decreased significantly. During pasteurization was cherry weight constant, brine increased, cherry decreased, percentage cherries decreased, volume, benzaldehyde and anthocyanine decreased significantly.
\end{abstract}

Keywords: Flavour, sourness, redness, processing, cherry, juice.

\section{INTRODUCTION}

Research in prediction of the optimum harvest time for cherries may be based on the relationship between the average flowering day $15^{\text {th }}$ May and the number of degree days that on average result in accumulation of about 1400 degree days on location of each single fruit plantation. The properties of mature sweet and sour cherries varies significantly in fruit size, colour, taste, sweetness, bitterness, acidity and in odour that make it possible to produce jam, cherry yoghurt and whole destoned cherries in brine with variation in sugar, acidity, colour and texture with attractive properties in yoghurts and destoned whole cherries. Previous research showed that berry and stone weight, acidity, soluble solids, anthocyanins, benzaldehyde, hydrogen cyanide, lightness, redness and yellowness may be used for prediction of maturity and picking time using linear equations obtained by factor analysis [1]. Therefore include this research a study in the relationships between cherry fruit properties and the quality characteristics of cherry fruit juice, jam, yoghurt and whole destoned cherries.

\section{MATerials AND Methods}

Fruits from six cherry cultivars including 'Dubbel Gorsem Krieck', 'Wielcin K', 'Nefris', 'Rexella', and 'Stevnsbær clone 23' grown at the experimental location $10^{\circ} 27^{\prime}$ ' (E) and $55^{\circ} 18^{\prime}$ ' $\mathrm{N}$ ) were picked by hand $1,4,7,11,14$ and 18 days after their first day of maturity and frozen to $-25^{\circ} \mathrm{C}$. Fruits from the cultivar 'Kelleris 16' grown on the same area were picked similarly and cooled in ice-water and used by processing of whole destoned cherries at the days of picking. Cherry fruit jam were processed using $600 \mathrm{~g}$ berries without stones, $600 \mathrm{~g}$ of sugar, $4.8 \mathrm{~g}$ pectin (LM $101 \mathrm{AS}$ ), $6 \mathrm{~mL}$ of $20 \mathrm{w} / \mathrm{w} \% \mathrm{Na}-$ benzoate, $6 \mathrm{~mL} 10 \mathrm{w} / \mathrm{w} \%$ potassium sorbate and 3-7 mL of $50 \mathrm{w} / \mathrm{w} \%$ citric acid. The frozen materials were carefully heated to $30^{\circ} \mathrm{C}$ and the $\mathrm{pH}$ levels were adjusted to 3.8 using a minor amount of the citric acid solution. The pectin was mixed with $20 \mathrm{~g}$ of sugar and added gently during heating to $100^{\circ} \mathrm{C}$ for one minute. After that were the remaining sugar and sodium benzoate solution added and the samples were heated once again and boiled for one minute before cooling at room temperature and storage in jars at $20^{\circ} \mathrm{C}$ for 73 days until analysis. Fruit yoghurt was prepared from $5 \mathrm{~kg}$ of yoghurt naturel, $747 \mathrm{~g}$ of cherry jam and treated in two minutes using a waring blender in order to homogenise the fruit yoghurt to a uniform mixture. The $\mathrm{pH}$ levels were 4.0 for the yoghurt and 3.8 for the ho- 
mogenised mixture, respectively. Fruits from the cherry cultivar 'Kelleris 16' were picked at optimum maturity, chilled in ice water for 2 hours, destined and processed at the day of harvest. The whole destoned and cooled fruits were processed using $200 \mathrm{~g}$ destoned cherries in $370 \mathrm{ml}$ glass jars filled using a sugar brine with $42.9 \mathrm{w} / \mathrm{w} \%$ sucrose and with 20 to $60 \mathrm{w} / \mathrm{w} \%$ and 0.4 per mille sodium benzoate. The jars were pasteurized for $30 \mathrm{~min}$ at $95^{\circ} \mathrm{C}$, cooled to room temperature and stored in coolers at $20^{\circ} \mathrm{C}$ for 73 days until analysis. Organic materials were homogenised for two minutes at maximum speed using a Robot-Coupe blender (Model R602VV, Vincennes, Cedex, France) or a hand-held blender (Braun, Miniper Compact, MR 404, Braun Gmbh, Kronberg, Germany). Soft parts from the fruits were separated from the stones by sieving. Dry matter was determined by drying of homogenised materials at $80^{\circ} \mathrm{C}$ to a constant weight after 20 hours. Non-soluble dry matter was obtained by drying and weighing of the materials in filters (Sleicher \& Schüll 520b, $185 \mathrm{~mm}$ ) from measurement of the soluble solids. Measurement of soluble solids and titratable acid were carried out using four parts of berries with or without cherry stones mixed with one part cold tap water $\left(12^{\circ} \mathrm{C}\right)$. Brown colour were measured using $2 \mathrm{~g}$ fruit materials, addition of $1 \mathrm{ml} 40 \% \mathrm{NaOH}$ and $1.00 \mathrm{~g}$ sodium dithionite and keeping the samples at $20^{\circ} \mathrm{C}$ for 20 hours. After that were the samples supplied with $0.5 \mathrm{~g}$ acetic acid and filled up to $50 \mathrm{ml}$ using water. The values from measurement of absorbance at $420 \mathrm{~nm}$ were applied as measure of the content of brown colourants. Non-damaged cherry fruit seeds were obtained by gently breaking of the cherry stones immediately before each experiment using a pair of nutcrackers. The contents of soluble solids were measured using a refractometer (Bellingham and Stanley, RF M800, Turnbridge Wells, Kent, UK) and the level of acidity was measured by titration of the samples to $\mathrm{pH} 8.1$ using $0.1 \mathrm{~N} \mathrm{NaOH}$ (Bie and Berntsen, Copenhagen). Anthocyanin content was measured using $100 \mathrm{~g}$ of carefully mixed cherries that were disintegrated in buffer solutions prepared using KCL/HCL at $\mathrm{pH} 1.0$. The contents of anthocyanin were measured using absorbance at $515 \mathrm{~nm}$, molar extinction coefficient of 29.600 and mole weight 445.2 of cyanidin-3-glucoside using a spectrophotometer (Shimadzu, MPS 2000, Kyoto, Japan). Drained weight was measured using a sight (ASTM E 11, Mesh 7, aperture 2.80) for 3 min. The contents of aroma compounds were measured using a Hewlett-Packard 7675A sampler with a sample size of $10 \mathrm{ml}$, involving a purge gas level of $\mathrm{N}_{2} 37.5 \mathrm{~mL}$, a five-minute pre-purge, 30-minute purge, pre-column filled with tenax-GC, temperature $20^{\circ} \mathrm{C}$, one-minute elution time and a cleaning temperature of $250^{\circ} \mathrm{C}$.

Table 1. Averages for raw materials used by processing of yoghurt and destoned fruit $(n=6)$.

\begin{tabular}{|c|c|c|c|c|c|c|c|}
\hline Cultivar & Picking & $\begin{array}{l}\text { Weight } \\
\mathrm{g}\end{array}$ & $\begin{array}{l}\text { Stone } \\
\mathrm{g}\end{array}$ & $\begin{array}{l}\text { Acidity } \\
\text { g } 100 \mathrm{~g}^{-1}\end{array}$ & $\begin{array}{l}\text { Brix } \\
\text { g } 100^{-1}\end{array}$ & $\begin{array}{l}\text { Colorant } \\
\text { mg } 100 \mathrm{~g}^{-1}\end{array}$ & $\begin{array}{l}\text { Flavour } \\
\text { point }\end{array}$ \\
\hline 'Stevnsbær clone 23' & $12^{\text {th }}$ Aug & $3.6 \mathrm{e}$ & $2.5 \mathrm{c}$ & $2.5 \mathrm{a}$ & $20.3 a$ & $218 \mathrm{a}$ & $6.7 \mathrm{a}$ \\
\hline 'Fanal' & $29^{\text {th }}$ July & $4.9 \mathrm{c}$ & $5.3 \mathrm{c}$ & $2.3 b$ & $16.3 d$ & $174 b$ & $6.0 \mathrm{~b}$ \\
\hline 'Beutelspacer Rexelle' & $29^{\text {th }} \mathrm{Jul}$ & $4.6 \mathrm{~d}$ & $7.7 \mathrm{~b}$ & $2.1 \mathrm{~d}$ & $16.2 \mathrm{~d}$ & $150 \mathrm{c}$ & $5.0 \mathrm{~d}$ \\
\hline${ }^{\circ}$ Crisana 2' & $3^{\text {rd }}$ Aug & $6.7 \mathrm{a}$ & $5.3 \mathrm{c}$ & $1.9 \mathrm{e}$ & $18.5 b$ & $84 \mathrm{e}$ & $6.1 \mathrm{a}$ \\
\hline 'Nefris' & $29^{\text {th }} \mathrm{Jul}$ & $4.9 \mathrm{c}$ & $2.6 \mathrm{c}$ & $2.5 \mathrm{a}$ & $16.3 \mathrm{~d}$ & $162 b$ & $5.2 \mathrm{c}$ \\
\hline 'Skyggemorel H2261' & $1^{\text {st }} \mathrm{Aug}$ & $5.3 b$ & $2.1 \mathrm{c}$ & $2.1 \mathrm{c}$ & $16.0 \mathrm{~d}$ & $92 d$ & $4.7 \mathrm{e}$ \\
\hline${ }^{\circ}$ Kelleris $16 '$ & $22^{\text {nd }} \mathrm{Jul}$ & $3.9 \mathrm{e}$ & $10.2 \mathrm{a}$ & $1.9 \mathrm{e}$ & $17.8 \mathrm{c}$ & $59 \mathrm{e}$ & 8.5 \\
\hline
\end{tabular}

A Hewlett-Packard 5890 series II Plus gas chromatograph (Hewlett-Packard, Avondale, PA) equipped with a split/ splitless injector $\left(200^{\circ} \mathrm{C}\right)$ and a flame ionisation detector (FID) operating at $230^{\circ} \mathrm{C}$ were applied by separation and quantification of the aroma compounds. The contents of benzaldehyde was measured using a Hewlett Packard HP 58OA GC-column $5 \mathrm{~m}$ steel i.d. 1/8 inch, carrier: diatomite, CW, 80-100 mesh, $10 \%$ Ucon-LB-1715, carrier gas $15 \mathrm{~mL}^{-1} \mathrm{~min}^{-1}$, column temperature $50-200^{\circ} \mathrm{C}, 4^{\circ} \mathrm{C}$ $\min ^{-1},{ }^{\circ} \mathrm{C} \min ^{-1}$, paper velocity $3 \mathrm{~mm} \mathrm{~min}^{-1}$ attenuator 2 exp. 10 , slope sensitivity, internal standard cyclohexanone with a retention time of 25.5 minutes.

The sensory panel consisted of four men and six women aged 28-36 years, who had trained for two years in sensory evaluation of fresh fruit and products processed from apple, strawberry, cherry and plum fruits. The preferred scale used by evaluation was 1 to 10 with 1 as the lowest and 10 as the highest intensity of each property.

\section{RESULTS AND DISCUSSION}

At the first picking day was the berry weight significantly highest for 'Crisana 2', followed by 'Skyggemorel H2261', equal for 'Fanal', 'Beutelspacer Rexelle' and 'Nefris' and significantly lowest for 'Stevnsbær clone 23' and 'Kelleris 16' (Table 1). Stone weight was significantly highest for 'Kelleris 16',decreased to 7.7 for 'Beutelspacer Rexelle', similar for, 'Fanal' and 'Chrisana' and sig- 
nificantly lower for 'Stevnsbær clone 23', 'Nefris' and significantly lowest for 'Skyggemorel H2261'. The contents of soluble solids were significantly highest for 'Stevnsbær clone 23' and significantly lower for 'Crisana 2' and 'Kelleris 16' and significantly lowest and similar for 'Fanal', 'Beutelspacer Rexelle', 'Nefris', 'Skyggemorel H2261', 'Beutelspacer Rexelle'. The contents of anthocyanin increased significantly for 'Kelleris 16', 'Crisana 2', 'Skyggemoral H2261', 'Beutelspacer Rexelle', 'Nefris', 'Fanal' to the highest content in 'Stevnsbær clone 23' [1]. The contents of anthocyanin in cherry fruits was below $100 \mathrm{mg} 100 \mathrm{~g}^{-1}$ for 'Crisana 2', 'Dubbel Gorsem Krieck', 'Kelleris 16', 'Nefris 338', 'Skyggemorel H 2261' and 'Stevnsbær new clone', while the content of anthocyanin varied from 100 to $200 \mathrm{mg} \mathrm{g}^{-1}$ for 'Rexella', 'Beutelspacer Rexelle', 'Fanal', 'Nefris' and 'Wielcin K'. Only 'Stevnsbær clone 23' had an anthocyanin content above $200 \mathrm{mg} 100 \mathrm{~g}^{-1}$. According to previous research varied the contents of anthocyanin between cherry cultivars from 2 to $36 \mathrm{mg} 100 \mathrm{~g} \mathrm{~g}^{-1}$ [2,3]. Other examples on the contents of anthocyanine in cultivars included 'Summit' 82.0, 'Stella'

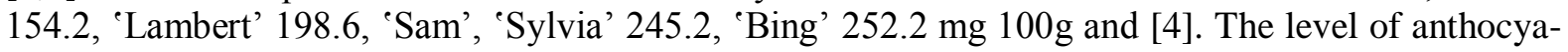
nin in frozen cherries depends on the storage temperature [5] because decreasing storage temperature

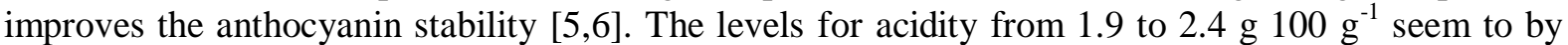

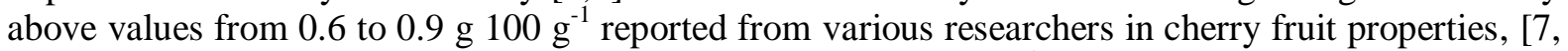

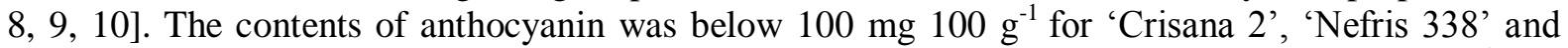
'Skyggemorel H 2261', while the content of anthocyanin varied from 100 to $200 \mathrm{mg} \mathrm{g}^{-1}$ for 'Beutelspacer Rexelle', 'Fanal', 'Nefris' and 'Wielcin K'. The highest average content of anthocyanin in this research was $226.4 \mathrm{mg} 100 \mathrm{~g}^{-1}$ found in fruits from 'Stevnsbær clone 23' [1].

Table 2. Colours of yoghurt produced using cherry jam $(n=6)$

\begin{tabular}{|l|c|c|c|}
\hline Cultivar & $\begin{array}{c}\text { Lightness } \\
\text { L }\end{array}$ & $\begin{array}{c}\text { Redness } \\
\mathrm{a}\end{array}$ & $\begin{array}{c}\text { Yellowness } \\
\mathrm{b}\end{array}$ \\
\hline 'Stevnsbær clone 23' & $72.0 \mathrm{c}$ & $21.8 \mathrm{a}$ & $1.9 \mathrm{~d}$ \\
\hline 'Fanal' & $74.0 \mathrm{bc}$ & $18.2 \mathrm{c}$ & $2.3 \mathrm{c}$ \\
\hline 'Beutelspacer Rexelle' & $75.2 \mathrm{~b}$ & $17.8 \mathrm{~d}$ & $2.8 \mathrm{~b}$ \\
\hline 'Crisana 2' & $78.3 \mathrm{a}$ & $15.1 \mathrm{e}$ & $2.8 \mathrm{~b}$ \\
\hline 'Nefris' & $72.9 \mathrm{c}$ & $19.2 \mathrm{~b}$ & $3.1 \mathrm{a}$ \\
\hline 'Skyggemorel H2261' & $78.2 \mathrm{a}$ & $14.2 \mathrm{c}$ & $3.3 \mathrm{a}$ \\
\hline
\end{tabular}

These values may be compared to the contents of anthocyanin that varied from 2 to $36 \mathrm{mg} 100 \mathrm{~g}^{-1}$ between cultivars [2,3]. Other examples are 'Summit' 82.0, 'Stella' 154.2, 'Lambert' 198.6, 'Sam', 'Sylvia' 245.2, and 'Bing' $252.2 \mathrm{mg} 100 \mathrm{~g}^{-1}$ [3]. The level of anthocyanin in frozen cherries depends on the storage temperature because decreasing storage temperature improved the anthocyanin stability [5, 6].The contents of both seeds, acidity, soluble solids and anthocyanin were significantly highest in 'Stevnsbær clone 23' that is used for processing of juices, whereas the contents of benzaldehyde were significantly highest in fruits from 'Kelleris 16' [1]. However, there is not a convincing relations hip between browning and the contents of soluble solids, inverted sugars or anthocyanin.

Table 3. Equilibration of sugar and fruit in destoned cherries (cv. 'Kelleris 16')

\begin{tabular}{|c|c|c|c|c|c|c|c|c|c|}
\hline Days & Product & Brine & Fruit & Product & Brine & Fruit & Product & Brine & Fruit \\
\hline & \multicolumn{3}{|l|}{$\mathrm{g}$} & \multicolumn{3}{|c|}{ Soluble solids g $100 \mathrm{~g}^{-1}$} & \multicolumn{3}{|c|}{ Acidity, g $100 \mathrm{~g}^{-1}$} \\
\hline 0 & $400 \mathrm{a}$ & $200 a$ & $200 \mathrm{a}$ & - & $43 a$ & $16 \mathrm{c}$ & $0.93 \mathrm{a}$ & $0.70 \mathrm{~b}$ & $1.86 \mathrm{a}$ \\
\hline 6 & $390 b$ & $241 b$ & $150 \mathrm{~b}$ & $75 a$ & $32 b$ & $24 b$ & $0.93 a$ & $0.70 \mathrm{~b}$ & $1.42 \mathrm{~b}$ \\
\hline 17 & $390 b$ & $241 b$ & $149 \mathrm{~b}$ & $75 a$ & $33 b$ & $25 b$ & $0.94 \mathrm{a}$ & $0.70 \mathrm{~b}$ & $1.34 \mathrm{c}$ \\
\hline 38 & $393 b$ & $243 b$ & $150 b$ & $75 a$ & $30 \mathrm{c}$ & $29 a$ & $0.97 \mathrm{a}$ & $0.70 \mathrm{a}$ & $1.04 d$ \\
\hline 48 & $391 b$ & $239 b$ & $152 \mathrm{~b}$ & $76 a$ & $30 \mathrm{c}$ & $30 \mathrm{a}$ & $0.97 \mathrm{a}$ & $0.84 b$ & $1.01 \mathrm{e}$ \\
\hline 73 & $394 a$ & $240 a$ & $154 \mathrm{~b}$ & $77 a$ & $30 \mathrm{c}$ & $30 \mathrm{a}$ & $0.97 \mathrm{a}$ & $0.94 a$ & $1.01 \mathrm{e}$ \\
\hline
\end{tabular}

The weight of product, brine, fruit and soluble solids of product were equilibrated after six days of storage (Table 1). Soluble solids in brine and fruit decreased and increased to a balance after 48 days, respectively. Acidity of product was equilibrated while acidity in brine and fruit increased and decreased, respectively. That resulted also in a balance after 48 days as for soluble solids.

Cherry fruits accumulate cyanogenic glucosides which, upon disruption of the seeds, are catabolized to hydrogen cyanide $(\mathrm{HCN})$ and benzaldehyde through enzymatic hydrolysis [8]. Contents of soluble

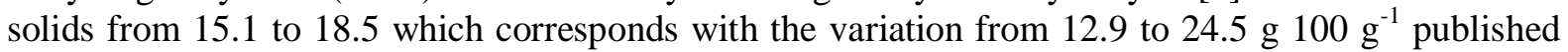
recently $7,8,9,10,11,12$. Data from processing and storage of whole destoned cherry fruit showed that weight of product, brine and fruit were equilibrated together with soluble solids in the product 
and brine. Acidity in the product and brine were also equilibrated after six days of storage, whereas soluble solids and acidity in the fruit increased significantly (Table 1).

Table 4. Effects of sugar in the brine. Pasteurized $30 \min 95^{\circ} \mathrm{C}(n=2)$

\begin{tabular}{|c|c|c|c|c|c|c|c|c|}
\hline $\begin{array}{l}\text { Weight } \\
\text { g }\end{array}$ & $\begin{array}{l}\text { Brine } \\
\mathrm{g}\end{array}$ & $\begin{array}{l}\text { Cherries } \\
\mathrm{g}\end{array}$ & $\begin{array}{l}\text { Sugar } \\
\text { g } 100 \mathrm{~g}^{-1}\end{array}$ & $\begin{array}{l}\text { Weight } \\
\text { g } 100 \mathrm{~g}^{-1}\end{array}$ & $\begin{array}{l}\text { Density } \\
\mathrm{g} / \mathrm{cm}^{3}\end{array}$ & $\begin{array}{l}\text { Cherries } \\
\text { g } 100 \mathrm{~g}^{-1}\end{array}$ & $\begin{array}{l}\text { Acidity } \\
\text { g } 100 \mathrm{~g}^{-1}\end{array}$ & $\begin{array}{l}\text { Berry } \\
\mathrm{cm}^{3}\end{array}$ \\
\hline $351 \mathrm{f}$ & $191 \mathrm{f}$ & $160 \mathrm{a}$ & - & $8.6 \mathrm{~g}$ & $1.03 \mathrm{~d}$ & $46 a$ & $1.6 \mathrm{a}$ & $185 a$ \\
\hline $369 \mathrm{e}$ & $209 \mathrm{e}$ & $160 \mathrm{a}$ & 20.0 & $17.6 \mathrm{f}$ & $1.07 \mathrm{c}$ & $43 a$ & $1.1 \mathrm{~b}$ & $176 b$ \\
\hline $381 d$ & $219 d$ & $162 a$ & 33.3 & $24.1 \mathrm{e}$ & $1.10 \mathrm{~b}$ & $43 a$ & $1.0 \mathrm{~b}$ & $171 \mathrm{~b}$ \\
\hline $388 \mathrm{c}$ & $230 \mathrm{c}$ & $158 b$ & 42.9 & $29.5 d$ & $1.13 \mathrm{ab}$ & $41 \mathrm{a}$ & $1.0 \mathrm{~b}$ & $166 b$ \\
\hline $400 \mathrm{~b}$ & $241 b$ & $159 \mathrm{~b}$ & 50.0 & $32.2 \mathrm{c}$ & $1.14 \mathrm{a}$ & $40 \mathrm{a}$ & $1.0 \mathrm{~b}$ & $159 \mathrm{c}$ \\
\hline $396 b$ & $238 b$ & $158 \mathrm{~b}$ & 55.5 & $36.8 b$ & $1.16 \mathrm{a}$ & $40 \mathrm{a}$ & $1.0 \mathrm{~b}$ & $166 \mathrm{c}$ \\
\hline $409 a$ & $247 a$ & $158 b$ & 60.0 & $39.2 \mathrm{a}$ & $1.17 \mathrm{a}$ & $40 \mathrm{a}$ & $1.0 \mathrm{~b}$ & $160 d$ \\
\hline
\end{tabular}

By increasing level of applied sugar increased net weight and brine, while the weight of cherries decreased significantly. Net weight and density increased, while the contents of cherries and acidity were equilibrated and berry volume decreased significantly (Table 2). The weight was stabilized, brine increased, cherries decreased, weight and volume decreased significantly. Benzaldehyde was degraded to benzoic acid and the weight of cherries decreased. Results from storage of pasteurized $\left(30 \mathrm{~min}\right.$ at $\left.95^{\circ} \mathrm{C}\right)$ whole destoned cherry fruits from the cultivar 'Kelleris $16^{\prime}$ ' and stored at $20^{\circ} \mathrm{C}$ for 73 days showed that the net weight was constant, cherry weight decreased and brine increased 20 $\mathrm{w} / \mathrm{w} \%$.

The data in table 3 shows that increasing pasteurization time not affected product weight, while the amount of brine increased significantly with $33 \mathrm{~g}$ and the contents of soluble solids, in the cherries, product, cherry volume, benzaldehyde and anthocyanin decreased significantly during pasteurization.

Table 5. Effects of pasteurization time on product quality characteristics $(n=2)$

\begin{tabular}{|c|c|c|c|c|c|c|c|}
\hline $\begin{array}{l}\text { Time, } \\
\text { min }\end{array}$ & $\begin{array}{l}\text { Weight } \\
\text { g }\end{array}$ & $\begin{array}{l}\text { Brine } \\
\mathrm{g}\end{array}$ & 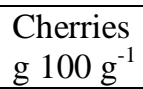 & $\begin{array}{l}\text { Weight } \\
\text { g } 100 \mathrm{~g}^{-1}\end{array}$ & $\begin{array}{l}\text { Volume } \\
\mathrm{cm}^{3}\end{array}$ & $\begin{array}{l}\text { Benzaldehyde } \\
\mathrm{mg} \mathrm{kg}^{-1}\end{array}$ & 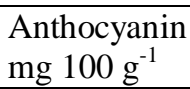 \\
\hline 10 & - & - & - & 84.4 & - & - & - \\
\hline 16 & $397 \mathrm{a}$ & $237 \mathrm{c}$ & $160 \mathrm{a}$ & $80.0 \mathrm{a}$ & $160 \mathrm{a}$ & $3.5 \mathrm{a}$ & $111.8 \mathrm{a}$ \\
\hline 32 & $392 a$ & $247 b$ & $145 b$ & $72.5 b$ & $151 b$ & $3.1 \mathrm{a}$ & $107.8 \mathrm{~b}$ \\
\hline 48 & $393 a$ & $255 b$ & $138 \mathrm{c}$ & $68.8 \mathrm{c}$ & $144 \mathrm{c}$ & $2.9 \mathrm{~b}$ & $109.3 \mathrm{c}$ \\
\hline 64 & $386 a$ & $253 b$ & $132 d$ & $66.0 \mathrm{~d}$ & $145 c$ & $2.7 \mathrm{~b}$ & $105.5 d$ \\
\hline 80 & $397 \mathrm{a}$ & $265 a$ & $132 \mathrm{~d}$ & $65.8 \mathrm{e}$ & $135 \mathrm{~d}$ & $2.7 b$ & $94.6 \mathrm{e}$ \\
\hline 96 & $397 \mathrm{a}$ & $270 \mathrm{a}$ & $127 \mathrm{e}$ & $53.5 \mathrm{f}$ & 130d & $2.6 \mathrm{c}$ & $93.5 \mathrm{f}$ \\
\hline
\end{tabular}

Data from determination of the composition of raw cherries 'Stevnsbær clone 23' and porridge processed from these cherries using an unknown recipe from one of the participating companies and an open cooking pot resulted in significantly decreases in benzaldehyde, anthocyanin, while soluble solids increased by addition of sugar according to the recipe, while acidity decreased significantly (Table 5). The major explanation for these decreases is addition of much water and common sugar. The composition of cherry fruit products obtained from local supermarkets encompassing one soft drink, four juices, two porridges, one jam, three deserts and raw fruit from 'Stevnsberry clone 23' grown at the experimental field and harvested during cherry fruit maturation (Table -4). A Hewlett-Packard 5890 series II Plus gas chromatograph (Hewlett-Packard, Avondale, PA) equipped with a split/ splitless injector $\left(200^{\circ} \mathrm{C}\right)$ and a flame ionisation detector (FID) operating at $230^{\circ} \mathrm{C}$ were applied by separation and quantification of the aroma compounds. The contents of benzaldehyde was measured using a Hewlett Packard HP 58OA GC-column $5 \mathrm{~m}$ steel i.d. 1/8 inch, carrier: diatomite, C-W, 80-100 mesh, $10 \%$ Ucon-LB-1715, carrier gas $15 \mathrm{~mL}^{-1} \mathrm{~min}^{-1}$, column temperature $50-200^{\circ} \mathrm{C}, 4^{\circ} \mathrm{C} \mathrm{min}^{-1},{ }^{\circ} \mathrm{C}$ $\mathrm{min}^{-1}$, paper velocity $3 \mathrm{~mm} \mathrm{~min}{ }^{-1}$ attenuator 2 exp. 10, slope sensitivity, internal standard cyclohexanone with a retention time of 25.5 minutes.

Table 6. Data from processing of porridge using $(n=3)$

\begin{tabular}{|l|c|c|}
\hline Compounds & Raw fruit & Stewed fruit \\
\hline Benzaldehyde $\mathrm{mg} \mathrm{kg}^{-1}$ & $4.9 \mathrm{a}$ & $1.1 \mathrm{~b}$ \\
\hline Anthocyanin, ${\mathrm{mg} 100 \mathrm{~g}^{-1}}^{-1}$ & $71.8 \mathrm{a}$ & $18.6 \mathrm{~b}$ \\
\hline Soluble solids, ${\mathrm{g} 100 \mathrm{~g}^{-1}}^{-1}$ & $14.4 \mathrm{~b}$ & $25.2 \mathrm{a}$ \\
\hline Acidity g $100 \mathrm{~g}^{-1}$ & $1.3 \mathrm{c}$ & $0.32 \mathrm{~b}$ \\
\hline
\end{tabular}




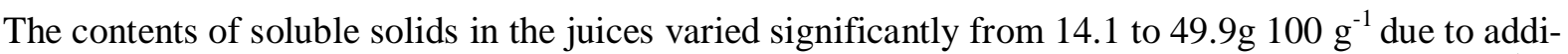

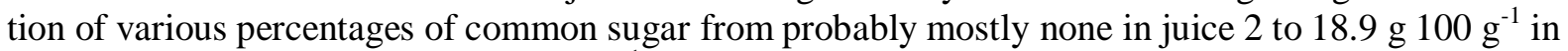

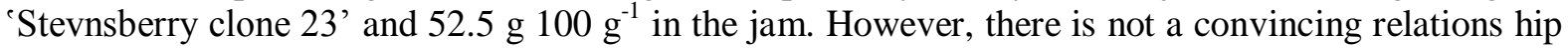
between browning and the contents of soluble solids, inverted sugars or anthocyanin. There occurred a low content of anthocyanins in the processed food by comparison to the contents of anthocyanins in raw cherries (Table 4). However, there is not a convincing relations hip between browning and the contents of soluble solids, inverted sugars or anthocyanin.

Table 7. Composition of cherry fruit products bought in food shops $(n=2)$

\begin{tabular}{|c|c|c|c|c|c|c|c|}
\hline Product & $\mathrm{pH}$ & 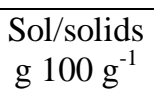 & 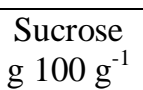 & 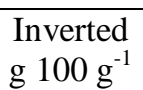 & $\begin{array}{l}\text { Anthocyanin } \\
\mathrm{mg} 100 \mathrm{~g}^{-1}\end{array}$ & $\begin{array}{c}\text { Browning } \\
\text { optical units }\end{array}$ & $\begin{array}{l}\text { Benzaldehyde } \\
\text { g } 100 \mathrm{~g}^{-1}\end{array}$ \\
\hline Soft drink & 3.1 & 32.2 & 63 & 37 & 11.5 & $1.1 \mathrm{f}$ & $6.1 \mathrm{a}$ \\
\hline Juice 1 & 3.5 & $14.1 d$ & $33 d$ & $67 a$ & 11.5 & $3.9 \mathrm{~d}$ & $2.9 \mathrm{~b}$ \\
\hline & 3.5 & $38.4 \mathrm{c}$ & $40 \mathrm{c}$ & $60 \mathrm{~b}$ & 10.5 & $5.3 \mathrm{c}$ & $1.0 \mathrm{~d}$ \\
\hline "“ & 3.5 & $49.9 a$ & $79 a$ & $21 d$ & 46.1 & $2.1 \mathrm{e}$ & $2.1 \mathrm{c}$ \\
\hline 4 & 3.4 & $40.6 \mathrm{~b}$ & $67 b$ & $33 c$ & 54.3 & 3.5 & $2.5 \mathrm{c}$ \\
\hline Porridge & 3.7 & $25.1 \mathrm{a}$ & $24 a$ & $76 a$ & $13.5 \mathrm{a}$ & $7.5 b$ & $1.2 \mathrm{~b}$ \\
\hline “" & 3.5 & $30.0 \mathrm{a}$ & $64 b$ & $36 b$ & $9.5 b$ & $10.0 \mathrm{a}$ & $1.5 \mathrm{a}$ \\
\hline Jam & 3.3 & 52.5 & 34 & 66 & 22.9 & 4.2 & $0.4 \mathrm{c}$ \\
\hline Destoned fruits & 3.6 & $12.6 \mathrm{c}$ & $41 \mathrm{a}$ & $59 \mathrm{c}$ & $77.5 b$ & $9.0 \mathrm{a}$ & $3.8 \mathrm{~b}$ \\
\hline “" & 3.5 & $26.4 \mathrm{a}$ & $5 c$ & $95 \mathrm{a}$ & - & $8.9 \mathrm{a}$ & $4.5 \mathrm{a}$ \\
\hline “" & 3.5 & $26.1 \mathrm{~b}$ & $11 \mathrm{~b}$ & $89 b$ & $139.1 \mathrm{a}$ & $8.9 \mathrm{a}$ & $3.8 \mathrm{~b}$ \\
\hline Stevnsbær Aug 23 & 3.4 & $12.9 \mathrm{c}$ & $13 a$ & 87 & $56.4 d$ & $12.5 \mathrm{a}$ & $8.9 \mathrm{a}$ \\
\hline Stevnsbær Aug 30 & 3.4 & $14.1 \mathrm{~b}$ & $3 c$ & 97 & $74.6 \mathrm{c}$ & $6.6 \mathrm{~d}$ & $8.1 \mathrm{~b}$ \\
\hline Stevnsbær Sep 5 & 3.7 & $14.6 \mathrm{~b}$ & $7 b$ & 93 & $84.1 b$ & $10.4 b$ & $7.8 \mathrm{~b}$ \\
\hline Stevnsbær Sep 10 & 3.8 & $18.1 \mathrm{a}$ & $14 \mathrm{a}$ & 86 & $105.5 \mathrm{a}$ & $7.6 \mathrm{c}$ & $6.5 \mathrm{c}$ \\
\hline
\end{tabular}

There occurred a low content of anthocyanins in the processed food by comparison to the contents of anthocyanins in raw cherries (Table 4). A high degree of sucrose inversion during freezing of cherries may be one of the reasons for browning during processing of cherry foods (Table 4). However, Juice 2 and 3 had a low content of sucrose, a high degree of inversion, low contents of anthocyanin and a more intensive browning in comparison to juice 4 and 5 that contained acetaldehyde and unknown 2 because of more heating by processing of pomace, jam and ethanol in the processed foods. Table 4 shows the retention times for the compounds observed in the samples with the aim to identify compounds that affects the flavour of the foods. Because of very high and very low contents of the identified compounds are the retention times marked with $\mathrm{h}$ for high and 1 for low concentrations, respectively.

Table 4. Retention times for compounds identified and quantified using gaschromatography $(n=3)$. $H$ is high and $L$ is low concentration.

\begin{tabular}{|l|l|l|l|l|l|l|l|}
\hline Compound & $\begin{array}{l}\text { Stevns- } \\
\text { berry }\end{array}$ & $\begin{array}{l}\text { Juice } \\
2 \& 3\end{array}$ & $\begin{array}{l}\text { Juice } \\
4 \& 5\end{array}$ & $\begin{array}{l}\text { Soft } \\
\text { drink }\end{array}$ & Jam & $\begin{array}{l}\text { Kelleris } \\
\text { pomace }\end{array}$ & $\begin{array}{l}\text { Kelleris } \\
\text { destoned }\end{array}$ \\
\hline \multicolumn{7}{|l|}{ Retention times, min } \\
\hline Acetaldehyde & & & $5.00 \mathrm{H}$ & & $4.6 \mathrm{H}$ & $4.7 \mathrm{H}$ & $4.7 \mathrm{~L}$ \\
\hline Unknown 1 & $6.2 \mathrm{~L}$ & $6.6 \mathrm{~L}$ & & & & & $6.2 \mathrm{~L}$ \\
\hline Ethanol & $9.4 \mathrm{~L}$ & $9.4 \mathrm{H}$ & $9.4 \mathrm{H}$ & $9.6 \mathrm{H}$ & & & $9.1 \mathrm{~L}$ \\
\hline Unknown 2 & & & $17.7 \mathrm{H}$ & & & & \\
\hline Unknown 3 & $16.5 \mathrm{~L}$ & $15.8 \mathrm{~L}$ & & $16.4 \mathrm{H}$ & $16.29 \mathrm{H}$ & $16.7 \mathrm{H}$ & \\
\hline Unknown 4 & $21.0 \mathrm{~L}$ & $20.6 \mathrm{~L}$ & & $20.4 \mathrm{H}$ & & $17.1 \mathrm{~L}$ & \\
\hline Unknown 5 & & & & 21.01 & & & \\
\hline Cyclohexanon & $23.5 \mathrm{H}$ & $24.5 \mathrm{H}$ & $24.6 \mathrm{H}$ & $25.65 \mathrm{H}$ & $23.59 \mathrm{H}$ & $24.2 \mathrm{H}$ & $23.2 \mathrm{H}$ \\
\hline Unknown 6 & $26.4 \mathrm{~L}$ & $26.3 \mathrm{~L}$ & & $27.7 \mathrm{~L}$ & & & \\
\hline Unknown 7 & & & & $29.4 \mathrm{~L}$ & & & \\
\hline Benzaldehyde & $28.9 \mathrm{~L}$ & $30.0 \mathrm{~L}$ & $29.9 \mathrm{H}$ & $30.0 \mathrm{H}$ & $31.7 \mathrm{~L}$ & $24.5 \mathrm{~L}$ & $0.01 \mathrm{~L}$ \\
\hline
\end{tabular}

Stevnsberry fruit, juice 2 and 3 and the soft drink did not contain acetaldehyde, whereas this compound occurred in juice 4 and 5, jam, pomace and destoned berries (Table 4). Unknown 1 occurred at a low level in cherry fruit odour, in juice 2 and 3 and destoned fruits. Ethanol occurred at low concentrations in the fruit and destoned cherries, while the concentration was higher in the two juices and the soft drink. Cyclohexanone are used as a reference compound by calculation of the contents of benzaldehyde that is the major odour compound in this research. The high levels of acetaldehydein juice 4 , 
5, jam and pomace is well known as indicators due to heating by processing of jam and pomace. However, this compound did not occur in destoned fruits. The levels of acetaldehyde in pomace and destoned cherries were significantly low may occur because the jam processing of jam may contain this compound. Ethanol occurs as a normal part in plant biology and it is the major compounds in fermented foods including wine and cherry foods. Unknown 2 occurs only in 4 four and 5 only and not in any of the fruits use in this connection. However it was found in a cherry fruit juice 5 and its occurrence together with acetaldehyde, ethanol and benzaldehyde may be due to addition of a few compounds in order to obtain cherry fruit odour from benzaldehyde that causes the typical cherry fruit odour as mentioned above. The soft drink contain no acetaldehyde but ethanol, unknown 3, 4, 5, 6, and 7 and benzaldehyde and the content of non-inverted sugar and the lowest content of brown colorants indicate that this juice not is a natural product.

\section{REFERENCES}

[1] Kaack, K (2016). Maturation and picking time for sweet cherries (Prunus avium) and sour cherries. European Food Research and Food Technology (In press).

[2] Chandra, A., Nair M.G. Iezzoni A. (1992). Evaluation and Characterization of the Anthocyanin pigments in cherries (Prunus). J. Agric. Food Chem.40, 967-969.

[3] Forni, E., Polesello, F., Torreggiani. D., (1993). Changes in anthocyanins in cherries (Prunus avium) during osmohehydration, pasteurization and storage. Food Chem. 48, $295-299$.

[4] Gao, L., Mazza, G., (1995). Characterization, quantitation, and distriution of anthocyanins and colourless phenolics in sweet cherries. J. Agric. Food Chem. 43, 343-346.

[5] Chaovanakilit A, Wrolstad RE (2004). Total anthocyanins and total phenolics of fresh and processed cherries and their antioxidant properties. J. Food Sci. FCT 67-FCT 72.

[6] Mattheis, J.P., Buchanan, D.A., Fellman, J.K. (1992). Volatile compounds emitted by sweet cherries (Prunus avium Cv. Bing) during fruit development and ripening. J. Agric. Chem. 40, 471-474.

[7] Serrano, M., Díaz-Mula H M, Zapata, PJ, Castillo S., Guilén, F.; Martínez-Romero, D.Valverde, J.M.; Valero D. 2009. Maturity stage at harve3st determines the fruit quality and antioxidant potential after storage o sweet cherry cultivars. J. Agric. Food Chem. 57, 3240-4236.

[8] Usenik, V., Fajt, N., Mikulic-Petkovsek, M., Slatnar A., Stampar, F., Veeric, R., (2001). Sweet cherry pomological and iochemical characteristics influenzed by rootstock. J. Agric. Food Chem. 58, 4928-4933.

[9] Pérez-Sánchez R; Morales-Corts MR, Gómez-Sanchez, MÁ 2013. Quality evaluation of sour and duke cherries cultivated in south-west Europe (2012). J. Sci Food Agric 93, 2523-2530.

[10] Girard, B. Kopp, T.G., (1998). Physiochemical characteristics of selected sweet cherry cultivars. J. Agric. Food Chem. 46, 471-476.

[11] Chaovanalikit, A., Wrolstad, R.E., (2004). Anthocyanin and polyphenolic composition of fresh and processed cherries. J. Food Sci. 69, 73-83.

[12] Khorshigi, S., Davarynejad, G., Tehranifar, A., Fallahi E., (2011). Effect of modified atmosphere packaging on chemical composition, antioxidant capacity, anthocyanin, and total phenolic content of cherry fruits. Hort. Environ. Biotechnol. 52, 471-481. 